RAFAŁ MAŃKO

University of Amsterdam, Netherlands

\title{
THE PLACE OF LEGAL TRADITION IN ARTUR KOZAK'S JURISCENTRIST THEORY OF LAW
}

\begin{abstract}
There can be no doubt that Professor Artur Kozak (1960-2009) was amongst the most original and innovative Central European legal theorists of the turn of the $20^{\text {th }}$ and $21^{\text {st }}$ century. His legal theory named 'juriscentrism', based on an unprecedented synthesis of philosophical interpretationism and anti-representationism, sociologocial constructivism, as well as pragmatist ethics (inspired by ethnocentrism), allowed to produce a fresh legitimising narrative for lawyers' power in society. The present paper aims to enquire about the place and role played by legal tradition within Kozak's jurisprudential project. Its main claim will be that legal tradition is a keystone of juriscentrism, as it is the basis for the identity and the reproduction of the legal community, the sole guarantor of the reasonableness of judicial decisions.
\end{abstract}

\section{PURPose:}

Evaluation of the role of legal tradition in Artur Kozak's project of juriscentrism.

\section{METHODS:}

Analysis of the works of Artur Kozak and of the secondary literature about his works. 


\section{Conclusions:}

The role played by tradition in Kozak's theoretical project cannot be underestimated. It can even be said that legal tradition permeates the entire juriscentrist enterprise. Legal tradition can be identified with Kozak's ius - the crystallised rules of the legal practice. Legal tradition is the foundation of legal method and at the same time a sour of its legitimacy. Legal tradition is the basis of the identity of the legal community. The social construction of a lawyer can be described as his socialisation within the legal tradition. Not so much in the positive law contained in codes, statutes and case-law, but rather in the legal tradition, characterised by a long-term existence, as opposed to the ephemeral manifestations of the juridical produced by legislators and judges. Tradition is, therefore, embodied in the legal community, and the legal community is, at the same time, the bearer of legal tradition. This allows to characterise juriscentrism as a form of legal traditionalism.

KeYwords: Artur Kozak, juriscentrism, legal tradition

\section{INTRODUCTION}

Artur Kozak was undoubtedly one of Poland's most talented and original legal theorists of the recent decades (Bator 2009, p. 114). In contrast to the hitherto diminant analytical paradigm, focusing on the linguistic side of law and inscribed into the broader phenonenon of hyperpositivism (cf. Mańko 2013), Kozak created and promoted an alternative theoretical project which he gave the name of 'juriscentrism'. Today, being a non-analytical legal theorist in Poland is something normal, "post-analytical" (Bator \& Pulka 2019) legal theory has become fashionable, not to mention post-modern and critical legal thinking which finally have found their place in the region (cf. Mańko et al. 2016). However, Kozak needs to be credited in acting as an 'icebreaker' who opened Poland's jurisprudential landscape to new intellectual challenges, especially those posed by postmodern legal movements.

In this short contribution I wish to focus on one specific aspect of Kozak's juriscentrist legal theory, namely the role of legal tradition. To this end, however, it is necessary to provide a brief introduction to juriscentrism in general, as it is not yet widely known to non-English speakers. The paper is, the refore, 
structured as follows: in section 2 I will provide a brief introduction to the legal theory of juriscentrism and in section 4 focus on the role of legal tradition in Kozak's theoretical project. Section 5 will conclude.

From a methodological standpoint, the present paper is conceived as an intervention in the history of legal thought. Artur Kozak's premature death in 2009 has made juriscentrism - at least in his original version - part of the history of legal thought. Hence the paper aims at answering the question concerning the place of legal tradition in Kozak's thought on the basis of an analysis of his writings, with particular reference to his two key monographs: The Limits of Juristic Discretional Power, in which he laid the foundations of juriscentrism, and the unfinished monograph on the History of Normativity, posthumously published as Analytical Thinking in Legal Theory and Legal Practice. In line with this research approach, I neither wish to evaluate Kozak's theory nor develop it, my sole goal being the identification of the place of legal tradition within Kozak's jurisprudential system.

The main claim I shall advance on the basis of my research is that legal tradition plays a key role in juriscentrism. However, in contrast to the prevailing approach to legal tradition, Kozak seemingly is not so much focused on the continuity of legal institutions and legal norms (e.g. those from Roman law or the Ius Commune), but rather emphasise the continuity of legal methodology, and especially the paradigm of legal interpretation. However, this does not mean that Kozak focuses exclusively on this aspect of legal tradition. He also seems to admit a certain 'hard core' of legal tradition (ius), composed presumably of general principles and fundamental concepts, which cannot be freely changed by the legislator. A special role in juriscentrism is played by the legal community - it is, on the one hand, the guardian of legal tradition and, on the other hand, it socialises future lawyers precisely by making them imbued within that tradition. 


\section{JURISCENTRISM AS AN ORIGINAL AND INNOVATIVE LEGAL THEORY}

Juriscentrism can be characterised as a systemic, holistic, sociological and internal legal theory (Mańko 2020a). It is systemic, because it forms an internally coherent (even if unfinished) system, based on well-chosen foundations, which justify its specific claims. It is holistic, because it aims at providing an account for the entirety of the juridical phenomenon, as opposed to fragmentary or local theories, which only have an ambition to explain and account for a specific part of the juridical (e.g. a theory of private law, or a theory of legal interpretation). It is sociological, because it rests upon the empirical legal reality as its point of departure, rathern than on some abstract assumptions taken as axioms. Finally, it is internal, because it rests upon the internal point of view (the jurists' view) which it seeks to defend and legitimise, as opposed to external (non-juristic) points of view.

The project of juriscentrism can be said to rest on three fundamental theoretical pillars: a philosophical one, a sociological one and an ethical one. The philosophical pillar of juriscentrism is concerned, above all, with epistemological questions (Kozak 2002, ch. 1 and 2). It boils down to the claim that the subject of cognition (the person who is gaining cognisance of some phenomenon, in casu the lawyer) and the object of cognition (the phenomenon which is being analysed by that person, in casu the law) are strictly connected with each other. Kozak, therefore, rejected both the traditional emphasis on the object (where the subject was absent), but also the Cartesian emphasis on the subject (the cogito). Kozak urged to finish the 'anti-Cartesian revolution': the subject of cognition should not become liberated from the object of cognition - whereas such freedom is perhaps less dangerous in the case of literary interpretation, it is nonetheless dangerous in the case of legal interpretation. However, Kozak was fully aware that there is no return to modernist theses (typical for classical positivism), whereby the legal cogito would be limited by legal texts. These, as such, do not limit the scope of discretion of interpreters. Instead, a limitation must be sought within the legal community and the socialisation of jurists. The philosophical fillar of juriscentrism also encompasses embracing the claims of anti-representationism, 
according to which judgements about the world cannot be verified by reference to some 'external reality', but rather only evaluated within a given institutional sub-world in which they were generated (Pichlak 2014, p. 232).

The first pillar of juriscentrism prepares the ground for the second, sociological pillar. The philosophical foundations of juriscentrism entail a rejection of traditional forms of accounting for the juridical and providing it with legitimacy. The sociological pillar creates new ones in their place. Relying heavily on the the sociology of knowledge of Peter L. Berger and Peter Luckmann (1991), Kozak posited that the social world is a construction, and it is composed of parallel and distinct 'insitutional sub-worlds' (subświaty instytucjonalne). The legal sub-world (the juridical) is but one of such sub-worlds (Kozak 2010a, 138). It exists in parallel with the political, economic or religious sub-world. Neither of them has a monopoly over 'truth' about the world - each produce its own narrative, which is true from the internal point of view of that subworld, but controversial or even unacceptable from the point of view of other sub-worlds. No institutional sub-world can claim superiority over the other ones. However, there is room for their cooperation. Specifically, the role of the juridical sub-world can be explaied by referring to the well-known metaphor of the twelvth camel of the Caliph (Kozak 2010a, p. 141). ${ }^{1}$ The story goes as follows: a Bedouin owned a herd of 11 camels and in his last will he divided them between his three sons in the following way: the eldest son was to receive half of the herd; the middle son was to receive one third of the heard, and the youngest son - one sixth. Obviously, the number 11 cannot be divided by 2, 3 or 6 . Hence, the Bedouin's sons were unable to execute their father's will. They had a dispute which they could not resolve using their own intellectual and social means. Therefore, they asked the Caliph - representing the Law in the metaphor - for aid. The Caliph's reply was simple. He lend them one supplementary camel, thus enlarging the herd to 12 . Now the division could be executed: the first son could receive half of the herd ( 6 camels); the middle son could receive $1 / 3$ of the herd ( 4 camels), and the youngest one could receive $1 / 6$ of the herd ( 2 camels). This way the original 11 camels were divided in line with the Bedouin's will, and the supplementary 12th camel could be returned to the wise Caliph. According to Kozak, law operates exactly as this supplementary 12th camel (Kozak 2010a, p. 141). 
Its presence is not undestantable to the participants of legal disputes, yet thanks to it the dispute can be effectively solved.

Having established the philosophical and sociological foundations of his theory, Kozak supplemented them with an important ethical component which he borrowed from the American pragmatist philosopher Richard Rorty - it constitutes the third theoretical pillar of juriscentrism. Rorty had proposed an ethical stance which he described as 'ethnocentrism. ${ }^{2}$ Ethnocentrism, adapted to Kozak's needs, gave birth to the name of the entire theory - 'juriscentrism.' The ethical or axiological elements of juriscentrism requires that lawyers have 'faith in law', that they act not only merely as cold 'experts', but rather as true 'believers. ${ }^{4}$ The third pillar of juriscentrism, which injects into it elements of a pragmatist ethic, completes the theoretical construction and allows to speak of a holistic and systemic system of legal theory. Without it, the theory would be incomplete - having rejected the traditional foundations in the philosophical step, and introduced relativism of parallel sub-worlds in the sociological step, Kozak needed to rebuild a legitimacy theory for the juridical by resorting to a pragmatist ethical claim.

Based on these three theoretical foundations, Kozak formulated the main tenets of juriscentrism, amongst which the most significant are:

1. the legal community is an institutional sub-world (Kozak 2010a, p. 103-104);

2. jurists are formed through socialisation in the legal community, especially through legal education (Kozak 2002, p. 140; Kozak 2010a, p. 173-174);

3. law is created at the time of its interpretation by jurists, not at the time of legislation or at the time of adjudication (Kozak 2010a, p. 62);

4. law (ius) should be identified with the rules of the legal discourse (as opposed to the positivist identification of law with legal norms) (Kozak 2010, p. 132);

5. the discretion enjoyed by jurists when interpreting the law is limited to a significant extent by the imperatives of the institutional sub-world which unburden them in interpreting the law (Kozak 2002, passim);

6. lawyers must adopt an internal point of view of believiers, defending its legitimacy vis-à-vis other institutional sub-worlds (Kozak 2010b, passim); 
7. law cannot exist without its authority (Kozak 2010a, p. 155), built precisely by lawyers-as-believers-in-law.

Juriscentrism is undeniably an affirmative legal theory, being an 'an attempt to defend law from postmodern liquidity and the fall of authorities that it entails' (Jabłoński 2012, p. 101), as well as to protect 'the juristic status quo, and more precisely, of a certain belief about that status quo, popular in contemporary jurisprudence, from postmodern critique that it is facing' (Sulikowski 2011, p. 112-113). The stance advocated by Kozak is - as I have highlited above - one of a believer, allowing Pichlak to claim that juriscentrism is in fact 'a faith that has overcome the trial of doubts and scepticism suggesting an answer to the final question. A juriscentrically oriented jurist (...) sees something more in the legal order, some specific value that makes it (...) worthy of some faith' (Pichlak 2014, 242).

There can be no doubt that Kozak's theoretical achievement, although unfinished due to his premature death, is highly original not only against the background of Polish legal theory, but also in a world scale. ${ }^{5}$ It seems that Kozak was indeed the first legal theorist to originally assemble philosophical interpretationism and anti-represenationism with sociological constructionism and ethical ethnocentrism in order to produce a coherent theoretical account of the juridical. ${ }^{6}$ 


\section{THE PLACE OF TRADITION IN ARTUR KOZAK'S JURISCENTRIST PROJECT}

Before embarking upon an analysis of the role of legal tradition within juriscentrism it is necessary to provide at least a working definition of the notion of 'legal tradition'. In his Legal Traditions of the World Glenn defined tradition as an:

extension of the past to the present (...) continuously transmitted in a particular social context for it to be of current relevance. (...) That what is brought from the past to the present (...) is information. A tradition is accordingly composed of information (...).' (Glenn 2010, p. 12-13)

In an earlier paper Glenn wrote:

...we reach a contemporary conclusion, for lawyers in an information age, that tradition is information, as opposed to its transmission or reaction to it. The study of tradition is therefore the study of the content and flow of large bodies of normative information over time and over space. (Glenn 2009, p. 341)

A different approach to the concept of a legal tradition was taken by John Henry Merryman. For him a legal tradition:

is a set of deeply rooted, historically conditioned attitudes about the nature of law, about the role of law in the society and the polity, about the proper organization and operation of a legal system, and about the way law is or should be made, applied, studied, perfected, and taught. The legal tradition relates the legal system to the culture of which it is a partial expression. It puts the legal system in cultural perspective. (Merryman \& Pérez Perdono 2007, p. 1)

Without aiming at an exhaustive analysis of the scholarly literature on legal tradition, and limiting myself to the definitions provided by Glenn and Merryman, I will understand legal tradition as the historically-determined element of legal culture concerning the fundamental questions of the nature of law, its interpretation, application and development. In this sense, tradition is information which is passed from generation to generation within the legal community. 
The centrality of legal tradition to juriscentrism follows from the way in which Kozak formulated the very concept of law, understood as ius (as opposed to lex). As Kozak wrote:

Law in the juristic sense is only that what binds us independently from our will. Law is constructed within a discourse, but the practice of discourse itself is not the law. A discourse is a network of relationships between speakers. Law cristallises in these relationships, but one cannot say that law is identical with them. (Kozak 2010a, p. 132)

The metaphor of 'cristallisation', used in the above quote, suggests a longterm process, one occuring naturally and producing a certain legacy (the sedimented material). Definitely, in this conception law is not the product of a one-off act of will, expressed either by the legislator or judge. In fact, in line with this approach, Kozak argued that the genesis of law ought to be perceived: not as an act but as a process extended between the moment when a statute is enacted and [the moment when a] judicial decision is taken on its basis. The genesis of law occurs in the movement between those two points, a movement which is subject to culturally shaped conventions, at least some of which has a necessary character and cannot be freely modified without far reaching changes in the functioning of the whole society. The law creates itself in this space permanently and always anew, but constantly according to the same rules. (Kozak 2010a, p. 62-63)

From the point of view of identifying the importance of legal tradition in Kozak's thought, one should pay particular attention to the concept of 'culturally shaped conventions'. Kozak argues that the creation (genesis) of law occurs between the moment of legislation (production of a legislative text) and the moment of adjudication (production of a judicial decision - in the Civil Law system traditionally viewed as an act of 'application of law' to an individual case. For Kozak, what is important occurs between legislation and adjudication. And this process - to wit, the process of legal interpretation - is not a process which occurs freely, but it is constrained precisely by the aforementioned 'culturally shaped conventions'. These conventions can definitely be identified with tradition (or treated as part of the legal tradition), especially that they are, at least to some extent, 'necessary' and cannot be modified. 
In line with this approach, Kozak opposes the ius of legal tradition to the ephemeral lex of the current legislator:

One can agree with the sceptical view that the text of the law is not sufficiently binding on us. But we are bound by conventions, according to which we determine the consequences of that text. [...] And those conventions are not accidental [...] [t] hey are the product of centuries-long experiences of our legal culture and in a postmodern society [...] they are the only ius towards which we can turn ourselves, faced with the chaotic and short-sighted creation of lex by contemporary politics. (Kozak 2010a, p. 248)

Once again, the ius o legal tradition, identified here with the 'conventions, according to which we determine the consequences' of legal texts, are binding. They are - as Kozak explicitly writes - 'the product of centuries long-experiences. Hence, they are part of the legal tradition. It is these conventions which are truly binding, as opposed to the leges which are the 'raw' material of legal interpretation. Kozak goes even as far as to state that:

The legislator [...] [m]ay [...] enact whatever he wishes and what suits his political needs, but autonomous courts [...] will apply only that what fits into the acceptable, culturally shaped muster. (Kozak 2010a, p. 149)

The legal tradition, which is truly binding, encompasses therefore not only a methodological toolbox (conventions of legal interpretation), but also the 'culturally shaped muster' which the judges will enforce, if necessary - giving it precedence before the lex created by politicians (which we could refer to as 'lex politica'). In the opposition of ius-tradition and the lex politica, Kozak obviously gives preference to ius, which is clearly distinct and independent from the leges:

A juriscentric model of legal practice [...] cannot presuppose the objectivity of meaning, and therefore it questions the cognitive character of interpretation (which does not exclude, that from an intrainstitutional perspective interpretation may appear to the interpreter as cognition). In this interpretive paradigm a status of reality is conferred not only upon rules of language, but [...] also upon law understood as a structure preceding a legal text [...] which has an independent existence.' (Kozak 2002, p. 141-142)

Law (ius) is understood here as 'a structure preceding a legal text'. That structure - undoubtedly shaped by tradition - has 'independent existence'. 
What is crucial here is the reality of legal culture, the 'intra-institutional reality' in Kozak's own words:

... the law acts through a socially shaped institutional structure which produces a specific, professional semantics. Thanks to this semantics it can ascribe specific cultural meanings to other elements of social worlds, thereby creating an intra-institutional reality. The reality of law rests upon the reality of culture, generated by society.' (Kozak 2010a, p. 103-104)

The role of legal tradition in juriscentrism is so significant that it even leads to a certain form of juridical statism. By founding his juriscentrist theory upon the basis of linguistic structuralism, Kozak was eager to take over the preference for diachronic stability of langue, and to obfuscate the synchronic mutability of parole (Pichlak 2011, p. 130). Just like de Saussure's langue is static, so is the juriscentrist notion of ius, of the rules governing legal practice, cristalised from those practices into a 'durable and autonomous decisional structure, shaping the behaviour and decisions of individual actors of legal practice' (Pichlak 2011, p. 132) are likewise static. As Pichlak pointed out:

A conception of practice [...] which place in its entre the problem of structure (norm) and its realisation must treat any change as a pathology, as a deviation. [...] The emphasis placed by juriscentrism upon the identity of the legal system [...] seems to confirm the hunch that in this project there is no place for a justified modification within the scope of practice.7 (Pichlak 2011, p. 133-134)

Juriscentrism is therefore a theoretical project which places at its heart the continuity of legal culture and the impact of tradition, treating it as a factor legitimising the political power vested in the legal community. This agenda places juriscentrism close to another forms of juristic traditionalism, such as, for instance, $19^{\text {th }}$ century Historical School (Historische Rechtschule) and Pandectism or $20^{\text {th }}$ century Neopandectism. ${ }^{8}$ What Juriscentrism and other forms of juristic traditionalism, such as Neopandectism, share in common is the emphasis on continuity of legal culture - in the case of juriscentrism, it is the continuity of the legal method, in the case of Neopandectism - the continuity and 'ongoingness' of the Roman Legal Tradition. Kozak's legal traditionalism, therefore, places the greatest emphasis not on the continuity of legal norms and legal institutions (e.g. those derived from Roman Law, 
the Roman-Canon Ius Commune or other earlier historical formations), but rather on the continuity of the legal method.

This statement needs to be qualified in two ways. Firstly, Kozak also encompasses, in his vision of the law, its preference for purely formal values. As Kozak wrote:

I am in favour of the hypothesis that [the categorial centre of legal thought] in Western culture lies in the formal aspect of law, whereas aspects related to its content (substance) have a secondary character. (Kozak 2002, p. 158-160)

Hence, the very form of law,${ }^{9}$ as a way of perceiving social reality by resorting to purely formal values, undoubtedly handed down both by the European Legal Tradition (both in its Civil Law and Common Law variations), is central to Kozak's understanding of the essence and operation of law.

The chief function of legal tradition in Kozak's system is to limit lawyers' discretion. A stable paradigm of interpretation, in his view:

on the one hand, protects us against the arbitrariness of individual lawyers, and on the other does not allow political conjectures, guiding the conduct of actual legislators, to become reflected in legal practice. (Kozak 2002, p. 152)

Legal method is thus understood as limiting individual lawyers' freedom of interpretation, and on the other hand limiting the democratic influence upon law, making it autonomous vis-à-vis politics. ${ }^{10}$ Discussing the notion of a 'rational legislator', which is an important theoretical construct in Polish analytical legal theory, Kozak pointed out that:

The rational legislator is [...] not the interpreter's alter ego, but represents the institutionalised reality of culture within which the interpreter exists. (Kozak 2002, p. 152)

The interpreter, therefore, is conceived as not using the notion of a 'rational legislator' just as an argumentative device, but rather as decoding some objective reality ('institutionalised reality of culture'), undoubtedly created over time (and thereby being a form of tradition), which is superior towards the lex and binding upon the interpreter himself. Tradition, embodied in and transmitted through institutionalised legal practice is crucial to judicial decision-making and to its predictability. As Kozak wrote:

...to the extent that a lawyer's activity is limited by the constraints set by the intrainstitutional reality, his acts cannot be deemed as free, and therefore 
cannot be deemed as an exercise of power vis-à-vis other participants of legal relationships. (Kozak 2002, p. 159)

In the context of the previous fragment it comes as no surprise that Kozak sought inspiration inter alia in the works of Arnold Gehlen. After recalling Gehlen's view that the a consequence of the reduction of the role of institutions in social life is growing sujbectivism, Kozak comments that within law 'must lead to the rejection of the fundamental values of the system' (Kozak 2002, p. 170). Acccording to Kozak, legal decision-making

under conditions of "deinstitutionalised" legal practice would be random, unpredictable, uncapable of being evaluated according to categories of formal justice and unjustifiable. Law would become a true game into the "judge's whim" [...]. (Kozak 2002, p. 170)

Thus, for Kozak, 'the more institutionalisation, the more democracy' (Kozak 2002, p. 170). Acknowledging that drawing inspiration from Gehlen can be 'ambigous' (ibid.) Kozak nevertheless argued that we live in a period of institutional crisis and that 'law is practically te only normative and axiological system which constitutes a centre around which a socially acceptable feeling of order could be constituted' (ibid., p. 171) The law can fulfil this function, according to Kozak, only if it is based on a 'certain form of order', because '[i]nstitutionalised with its [... "unburdened" cognition [...] [is] a necessary condition for law to fulfil the function of a language of social communication' (ibid.). Nowhere does Kozak assert the existence of a democratic legimitation of the 'ius' understood as the order of legal discourse. To the contrary, he openly contrasts this intrainstitutional ius with the democratically enacted lex, giving ius primacy over lex. Hence tradition is valued higher than democracy. Interestingly, Kozak tries to downplay this risk by pointing to the fact that the 'Juridification of democratic values makes them into an element of the institutional structure of law' (ibid.). He gives the interesting example of the Rechstaat, noting that the Polish pouvoir contituant coulnd to create it by itself, but only 'accept a construct created indepdently from it, within the universe of European legal culture' (Kozak 2010a, p. 211). The Rechtstaat is actually one of the few concrete legal institutions that Kozak mentions in his works. 


\section{Conclusions}

Every theoretical project is enmeshed in a given historical reality during which it was conceived. Artur Kozak's period of academic activity (1982-2009) spans over the latter decade of state-socialist People's Poland, covers the period of dynamic changes from socialism to capitalism (1989-1990), and the first two decades of the democratic and capitalist 'Third Republic'. Kozak was an eyewitness of the crumbling of the old order and the creation of a new one. As a jurist, he also witnessed an unprecedented growth of the power of lawyers in society, and sought to provide a solid theoretical foundation for its legitimacy. The period of transformation was also a period of revival of Poland's legal traditions and a reinforcement of the role played by the European legal tradition within Polish legal culture. The socialist legal tradition, originating in the Soviet Union, was rejected, and the Polish legal community sought after a symbolic revival of the European legal tradition.

The role played by tradition in Kozak's theoretical project cannot be underestimated. It can even be said that legal tradition permeates the entire juriscentrist enterprise. Legal tradition can be identified with Kozak's ius - the crystallised rules of the legal practice. Legal tradition is the foundation of legal method and at the same time a sour of its legitimacy. Legal tradition is the basis of the identity of the legal community. The social construction of a lawyer can be described as his socialisation within the legal tradition. Not so much in the positive law contained in codes, statutes and case-law, but rather in the legal tradition, characterised by a long-term existence, as opposed to the ephemeral manifestations of the juridical produced by legislators and judges. Tradition is, therefore, embodied in the legal community, and the legal community is, at the same time, the bearer of legal tradition. This allows to characterise juriscentrism as a form of legal traditionalism. 


\section{REFERENCES}

Bator, A., Pulka, Z. (2019). A Post-Analytical Approach to Philosophy and Theory of Law. Berlin: Peter Lang.

Bator, A. (2009). Artur Kozak (1960-2009). Państwo i Prawo 8: 113-115.

Berger, P., Luckmann T. (1991). The Social Construction of Reality: A. Treatise, in The Sociology of Knowledge. London: Penguin.

Glenn, H. P. (2009). A Concept of Legal Tradition. Queen's Law Journal 34: 427-446.

Glenn, H. P. (2010). Legal Traditions of the World. Cambridge: Cambridge University Press. 4th edition.

Jabłoński, P. (2012). Pytanie o prawo w kontekście konfliktu między hermeneutyka podejrzen i hermeneutyka zaufania [The Question Concerning the Law in The Context of the Conflict Between the Hermeneutics of Suspicion and the Hermeneutics of Trust]. M. Pichlak (ed.). Profesjonalna kultura prawnicza [Professional Juristic Culture]. Warszawa: Scholar.

Kozak, A. (2010a). Myślenie analityczne w nauce prawa i praktyce prawniczej [Analytical Thinking in Legal Science and Juristic Practice]. Wrocław: Wydawnictwo Uniwersytetu Wrocławskiego. Edited posthumously by Maciej Pichlak.

Kozak, A. (2010b). Dylematy prawniczej dyskrecjonalności. Między ideologią polityki a teorią prawa [Dilemmas of Lawyers' Discretionality: Between the Ideology of Politics and Legal Theory]. In Wiesław Staśkiewicz and Tomasz Stawecki (eds.), Dyskrecjonalność w prawie [Discretionality in Law], Warszawa: Lexis Nexis.

Kozak, A. (2002). Granice prawniczej władzy dyskrecjonalnej [The Limits of Lawyers' Discretional Power]. Wrocław: Kolonia Limited.

takomy, J. (2019). The space of the political in legal interpretation: (some remarks on the Dworkin-Fish debate). In Law, space and the political: an East-West perspective, 127137. Częstochowa: Wydawnictwo im. S. Podobińskiego Akademii im. Jana Długosza Edited by Paulina Bieś-Srokosz, Rafał Mańko, Jacek Srokosz.

Łakomy, J. (2020). Critical jurisprudence of Duncan Kennedy and the status of the theory of legal interpretation. Krytyka Prawa 12(3): 70-89. DOI: 10.7206/kp.2080-1084.396 Mańko, R. (2003). European Private Law - In Pursuit of Unity. Warsaw University Law Review 2(1/2): 110-131. Available at: https://www.academia.edu/47684325/ European_Private_Law_In_Pursuit_of_Unity?auto=download [visited: 28 June 2021]. Mańko, R. (2013). Weeds in the Gardens of Justice? The Survival of Hyperpositivism in Polish Legal Culture as a Symptom/Sinthome. Pólemos Journal of Law, Literature and Culture 7(2): 207-233.

Mańko, R. (2020a). Artur Kozak's juriscentrist concept of law: a Central European innovation in legal theory. Review of Central and East European Law 45: 334-375. DOI: https://doi.org/10.1163/15730352-bja04502003 
Mańko, R. (2020b.). Legal Form, Ideology and the Political. In Legal Scholarship and the Political: In Search of a New Paradigm. Warszawa: C.H. Beck. Edited by A. Sulikowski, R. Mańko, J. Łakomy.

Mańko, R. (2021). Judicial Decision-Making, Ideology, and the Political: Towards an Agonistic Theory of Adjudication. Law and Critique. https://doi.org/10.1007/s10978021-09288-w

Mańko, R., Cercel, C., Sulikowski, A. (2016). Law and Critique in Central Europe: Questioning the Past, Resisting the Present. Oxford: Counterpress.

Merryman, J. H., Pérez-Perdomo, R. (2007). The Civil Law Tradition: an Introduction to the Legal Systems of Europe and Latin America. Stanford: Stanford University Press. 3rd edition.

Pichlak, M. (2011). Tożsamość prawa w juryscentrycznej wizji praktyki prawniczej. In Paweł Jabłoński et al. (eds.), Perspektywy juryscentryzmu [Perspectives of Juriscentrism], Wrocław: Prawnicza i Ekonomiczna Biblioteka Cyfrowa. Available: http://www.bibliotekacyfrowa.pl/Content/38049/PDF/0001.pdf [visited: 28 June 2021]

Pichlak, M. (2014). Artura Kozaka cierpliwość wobec prawa [Artur Kozak's Patience Towards the Law]. Filozofia Publiczna i Edukacja Demokratyczna 3(1): 226-242. OI: 10.14746/fped.2014.3.1.12.

Rorty, R. (1991). Objectivity, Relativism, and Truth: Philosophical Papers, Volume 1. Cambridge: Cambridge University Press.

Sitek B. (2017). Prawo jako wartość. Rozważania o autonomii i ponadczasowości prawa w świetle zjawiska ponowoczesności [Law as Value: Discussions on the Autonomy and Intemporality of Law in the Light of the Postmodern Phenomenon]. In J. Jeżewski, A. Pawlak (eds.), Człowiek - Prawo - Państwo. Księga jubileuszowa prof. S. L. Stadniczenko. Warszawa.

Sitek, B. (2018). Od antropocentryzmu prawniczego do ekonomizacji prawa [From Juristic Anthropocentrism to the Economisation of Law]. In G. Dammacco, B. Sitek, O. Cabaj (ed.), Człowiek pomiędzy prawem a ekonomia w procesie integracji europejskiej. OlsztynBari.

Smits, J. (2002). The Making of European Private Law: Towards a Ius Commune Europaeum as a Mixed Legal System. Oxford-Antwerp-New York: Intersentia.

Sulikowski, A. (2011). Postmodernistyczne tropy w jursycentryzmie [Postmodern Tropes in Juriscentrism]. In Paweł Jabłoński et al. (eds.), Perspektywy juryscentryzmu [Perspectives of Juriscentrism]. Wrocław: Prawnicza i Ekonomiczna Biblioteka Cyfrowa. Available: http://www.bibliotekacyfrowa.pl/Content/38049/PDF/0001.pdf [visited: 28 June 2021]

Sulikowski, A. (2019). Law after the Death of God. In Andrzej Bator and Zbigniew Pulka (eds.), A Post-Analytical Approach to Philosophy and Theory of Law. Berlin: P. Lang. Teubner, G. (2001). Alienating Justice: On the surplus value of the twelfth camel. In D. Nelken, J. Přibán (eds.), Consequences of Legal Autopoiesis. Dartmouth: Ashgate. 


\section{ENDNOTES}

${ }^{[1]}$ A. Kozak tells the story following Teubner (2001).

${ }^{[2]}$ Cf. Rorty 1991, p. 13: '...one consequence of antirepresentationalism is the recognition that no description of how things are from a God's-eye point of view, no skyhook provided by some contemporary or yet-to-be-developed science, is going to free us from the contingency of having been acculturated as we were. Our acculturation is what makes certain options live, or momentous, or forced, while leaving others dead, or trivial, or optional.'

${ }^{[3]}$ Cf. Kozak 2002, p. 138: 'It seems that the new model of legal practice [...] could be best described by the adjective "juriscentrist". This term consciously refers to Rorty's conception of ethnocentrism as the foundation of truth. Rorty, accepting that the reality of cultural objects does not have a strictly extra-cogitational character (first thesis of interpretationism) searched for their justification in the social forms of human existence, in culture produced by society in the network of internal and external interactions and shaping individual members of society in a manner functional to the needs of the entire whole (second thesis of interpretationism). One can think in a similar way about contemporary Western legal systems.'

${ }^{\text {[4] }}$ Cf. Kozak 2010b, p. 68: 'We have [...] the choice between a lawyer consciously affirming the internal reality of the law and a lawyer consciously questioning it. Because I like to think about the law as a form of secular religion, I will refer to the first as a "Believer", and to the latter as an "Expert" in law. The difference between them is analogical to that which exists between a theologist and religion studies scholar, or - even more appropriately - between Christian and Muslim experts on the Bible and Koran. The Believer and Expert work on exactly the same set of artefacts, but have an entirely different approach to their cultural context, i.e. to the legal tradition, to unwritten principles and tacitly accepted values. The former takes an affirmative approach to them as to a significant and important whole, whereas the latter is sceptical about them - he uses them selectively and instrumentalises them with regard to a different universe of meanings.'

${ }^{[5]}$ I have presented an outline of Kozak's legal theory to various audiences during four international conferences (28th Critical Legal Conference, Queen's University in Belfast, September 2013; 6th CEE Forum, University of Zagreb, May 2014; 31st Critical Legal Conference, Kent Law School, September 2016; international conference on "History of Legal Concepts in the 20th century: Russia and Western Europe in Dialogue", HSE Saint-Petersburg, October 2018) and all international 
participants agreed that his theory is highly original and incomparable with any other jurisprudential project known to them.

${ }^{[6]}$ The limited framework of the present paper does not allow to make such comparisons, yet it would be highly inspiring to compare side-by-side juriscentrism with other contemporary projects of non-positivist legal theory, such as integral legal theory (Ronald Dworkin) or critical legal theory (Duncan Kennedy, Costas Douzinas). The contrast with Kelsenian or Hartian positivism is obvious, yet a detailed study of the differences between juriscentrism and other non-positivist theories could shed a new light on Kozak's jurisprudential enterprise.

${ }^{[7]}$ Ibid., p. 133-134.

${ }^{[8]}$ I borrow the term from Jan Smits to describe efforts at reconstructing a 'new Ius Commune' inter alia by a broad return to the Civilian Tradition, previously broken by the codifications (Smits 2002, p. 44). For a brief restatement of neopandectist argumentation for an organic development of law, rather than codification see e.g. Mańko 2003.

${ }^{[9]}$ On law as form see e.g. Mańko 2020b with further references.

${ }^{[10]}$ On the autonomy vs. instrumentalisation of law see e.g. Sitek 2017; Sitek 2018. On the relationship between legal interpretation and the political see e.g. Eakomy 2019; Łakomy 2020; Mańko 2021. 